\title{
Thyroid disturbances in children treated with combined pegylated interferon-alpha and ribavirin for chronic hepatitis C
}

\author{
Yasser K. Rashed, $M D^{1}$, Fatma A. Khalaf, $\mathrm{MD}^{2}$, Sobhy E. Kotb, $\mathrm{MRCPCH}^{3}$ \\ ${ }^{1}$ Department of Pediatric Hepatology, National Liver Institute, Menoufia University, Menoufia, Egypt; ${ }^{2}$ Department of Clinical Biochemistry, National Liver Institute, \\ Menoufia University, Menoufia, Egypt; ${ }^{3}$ Department of Pediatric Medicine, Ministry of Health Hospital, Menoufia, Egypt
}

Background: Immunomodulatory properties of interferon (IFN) have been documented. It may induce autoimmune diseases such as autoimmune thyroiditis with hypo- or hyperthy. roidism. In addition, it may impair thyroid hormone synthesis through affecting iodide organification in thyroid gland.

Purpose: The aim of this study was to describe thyroid function tests disturbances in children with chronic hepatitis $\mathrm{C}$ $(\mathrm{CHC})$ receiving pegylated interferon-alpha (PEG IFN- $\alpha$ ) plus ribavirin.

Methods: Fifty children with $\mathrm{CHC}$ virus infection who received combined pegylated interferon-alpha with ribavirin were selected. Other 50 apparently healthy children of matched age and sex (considered as control group) were selected. All children (100) were subject to liver function tests, virological studies, and follow-up of thyroid function test during and after the treatment course.

Results: Our study showed that $28 \%$ of children received combined PEG IFN- $\alpha$ plus ribavirin showed subclinical hypothyroidism. After 24 weeks treatment with combined therapy of IFN plus ribavirin, the mean level of thyroid stimulating hormone (TSH) was $3.23 \pm 88 \mathrm{mU} / \mathrm{mL}$, while TSH was $1.16 \pm$ $0.77 \mathrm{mU} / \mathrm{mL}$ before starting treatment. On the other hand, mean TSH was $1.09 \pm 0.92 \mathrm{mU} / \mathrm{mL}$ in normal control group.

Conclusion: This study revealed an association between subclinical thyroid dysfunction and treatment with IFN-alpha and ribavirin in children. Further studies on larger number of patients and longer follow-up duration are recommended for further confirmation.

Key words: Interferon, Thyroid, Ribavirin, Hypothyroidism

\section{Introduction}

Hepatitis $\mathrm{C}$ virus (HCV) infection is a world health problem, affecting over 160 million people worldwide. Liver cirrhosis (LC) and hepatocellular carcinoma (HCC) are well-known complications related to chronic hepatitis $\mathrm{C}$ (CHC) infection. ${ }^{1)}$ Accurate incidence of chronic HCV infection in Egyptian children is not properly known. ${ }^{2)}$

Transmission of HCV differs in different areas of the world. Intranatal transmission is common in well-developed countries while horizontal transmission is common while in developing countries. ${ }^{3)}$ Some factors can increase the morbidity of HCV infection in as obesity, malignant tumors, chronic hemolytic anemia needed recurrent blood transfusions, and coinfected with human immunodeficiency virus or hepatitis B virus (HBV). ${ }^{4)}$ Complications like hepatocellular damage and LC are rare in children in comparison to adults. ${ }^{5)}$

Until recently, pegylated interferon with ribavirin is the only recommended treatment of $\mathrm{CHC}$, first approved in December 2008. ${ }^{6}$ Early treatment in children prevents the long-term complications of chronic HCV infection. ${ }^{5)}$ Such treatment may induce autoimmune diseases as autoimmune thyroiditis, with hypo- or hyperthyroidism and interfere with the organification of iodide leading to impairment of thyroid hormone synthesis.7)

The aim of this study was to describe disturbances of thyroid function tests in children with $\mathrm{CHC}$ receiving pegylated interferon-alpha (PEG IFN- $\alpha$ ) plus ribavirin.

\section{Methods}

Fifty children with chronic HCV infection, followed-up from June 2010 till April 2016 were included in the primary selection. Fifty healthy children of the same age and sex considered as a control group submitted for follow-up and thyroid function tests. The study was revised and approved by the local ethical committee and Institutional Review Board (IRB) of National Liver Institute (IRB00003413). Legal guards of participants provided informed consent to participate in the study. Patients

Corresponding author: Yasser K. Rashed, MD. Department of Pediatric Hepatology, Gastroenterology and Nutrition - National Liver Institute, Menoufia University, 32511 Shebin El-koom, Menoufia, Egypt

E-mail: yasserrashed79@yahoo.com, https://orcid.org/0000-0001-9484-1238

Received: 7 October, 2018, Revised: 18 August, 2019, Accepted: 21 August, 2019

This is an open-access article distributed under the terms of the Creative Commons Attribution Non-Commercial License (http://creativecommons.org/licenses/bync/4.0/) which permits unrestricted non-commercial use, distribution, and reproduction in any medium, provided the original work is properly cited.

Copyright (c) 2020 by The Korean Pediatric Society 
with the following conditions were excluded: (1) coinfection with HBV, (2) peripheral blood neutrophils count $<1.5 \times 10^{3} /$ $\mathrm{mL}$, platelet count $<70 \times 10^{3} / \mathrm{mL}$ or hemoglobin level lower than $10 \mathrm{~g} / \mathrm{dL}$, (3) concomitant serious medical illnesses, such as; malignancy, autoimmune diseases, severe cardiopulmonary disease, uncontrolled diabetes mel-litus, or thyroid diseases.

All patients and healthy control children had:

(1) Liver function tests (aspartate aminotransferase, alanine aminotransferase [ALT], alkaline phosphatase, gamma glutamyl-transferase, total bilirubin direct bilirubin, total proteins, and albumin). Tests were carried out using Integra 400 auto analyzer (Roche diagnostics Corp., Hague Road, IN, USA).

(2) Viral markers, using enzyme-linked immunosorbent assay (ELISA) technique. HCV antibodies for both groups were done by kit from Inngenetics (Ghent, Belgium; Pawlotsky, 2002). HBV surface antigen and HBV core antibodies (HBcIgM and $\mathrm{HBclgG}$ ) were done by ELISA technique, by kit from Sorin Biomedica Co. (Spain).

(3) Detection of HCV-RNA in the sera (for positive HCV antibodies only). It was done using COBAS Ampliprep/ COBAS TaqMan, Roche Molecular Systems, Inc. (Branchburg, NJ, USA). It is a nucleic acid amplification test for the quantification of HCV-RNA.

The diagnosis of $\mathrm{CHC}$ was made by a persistent or intermittent elevation of ALT, the upper limit of laboratory normal was 40 IU/L over a 6-month period, anti-HCV positivity and detection of HCV-RNA in the sera (for positive HCV antibodies only).

(4) Liver biopsy was done for the diseased group only, after sedation with midazolam $(0.3 \mathrm{mg} / \mathrm{kg} /$ dose $)$, by true cut needle before IFN therapy. Biopsy specimens were fixed in formalin-buffered saline, embedded in paraffin followed by a histological examination using hematoxylin and eosin stains, orcien stain and Periodic acid Schiff stain for routine histopathological evaluation. Hepatic necro-inflammatory activity and liver fibrosis were evaluated according to Ishak staging and grading scores.

(5) Thyroid stimulating hormone (TSH) was measured by (immotile 1000, Siemens, Pittsburgh, PA, USA), while free thyroxin (FT4) and free triiodothyronine (FT3) were done before starting treatment and at the end of treatment for the diseased group were measured by radioimmunoassay using an automated system (Roche Diagnostics). Reference range for TSH was $0.4-4.0 \mathrm{mU} / \mathrm{L}$, for FT3 was 3.5$5.5 \mathrm{pmol} / \mathrm{L}$, and for FT4 was $10.0-26.0 \mathrm{pmol} / \mathrm{L}$.

(6) Antithyroglobulin antibodies and antithyroid peroxidase in case of clinical thyroiditis.

Patients with chronic HCV infection (50), received antiviral therapy consisting of PEG IFN- $\alpha 2 b$ in a dose of $60 \mu \mathrm{g} / 1.73 \mathrm{~m}^{2} /$ wk subcutaneously (PEG-interferon, Schering-Plough Brinny, Kenilworth, NJ, USA) plus ribavirin $15 \mathrm{mg} / \mathrm{kg}$ /day orally.

According to sustained virological response (SVR) (undetectable HCV-RNA at 24 weeks after treatment completion), patients were classified into 2 groups, responders and nonres- ponders.

Data were analyzed using the IBM SPSS ver. 18.0 (IBM Co., Armonk, NY, USA). Qualitative data were expressed as frequency and percentage.

The study was revised and approved by the local ethical committee and Institutional Review Board (IRB) of National Liver Institute (IRB No. 00003413).

\section{Results}

Hundred children divided into 2 groups, chronic HCV group and normal control group, each group was 50 children.

(1) The first group includes children with chronic HCV, 32 males (64\%) and 18 females (36\%) were further subdivided in 2 subgroups:

(a) Responders: who achieved SVR, were 29 patients, 19 males and 10 females.

(b) Nonresponders: who did not achieve SVR, were 21 patients, 13 males and 8 females.

(2) Healthy control group. Fifty healthy children (30 males and 20 females), with matched age were considered as control group (Table 1).

The mean age was $11.35 \pm 3.13$ years among patients group with $\mathrm{CHC}$, while in normal control group the mean age was $11.47 \pm 4.12$ years. Body mass index (BMI) was $19.1 \pm 3.3 \mathrm{~kg} / \mathrm{m}^{2}$ in diseased group while control group has BMI of $19.6 \pm 2.9 \mathrm{~kg} /$ $\mathrm{m}^{2}$ (Table 2).

At the end of 24 weeks treatment with combined therapy of IFN plus ribavirin, the mean level of FT3 was $4.24 \pm 0.33 \mathrm{pmol} / \mathrm{L}$ (range, 3.5-5.5 pmol/L), FT4 was $17.05 \pm 29.00 \mathrm{pmol} / \mathrm{L}$ (range, $10.0-26.0 \mathrm{pmol} / \mathrm{L}$ ), TSH was $3.23 \pm 88.00 \mathrm{mU} / \mathrm{mL}$ (range, 0.4 $4.0 \mathrm{mU} / \mathrm{L}$ ), while the basal level (before starting treatment) FT3 was $4.42 \pm 0.50 \mathrm{pmol} / \mathrm{L}, \mathrm{FT} 4$ was $17.44 \pm 0.24 \mathrm{pmol} / \mathrm{L}$, and TSH was $1.16 \pm 0.77 \mathrm{mU} / \mathrm{mL}$ (Table 3).

TSH level at the end of treatment (patient group) was less than $4 \mathrm{mU} / \mathrm{ml}$ in 36 patients, 4 to $<10 \mathrm{mU} / \mathrm{mL}$ in 13 patients and $>10 \mathrm{mU} / \mathrm{mL}$ in one patient only. Then mean TSH was $3.23 \pm 88$ $\mathrm{mU} / \mathrm{mL}$ in Pegylated interferon treated children at the end of treatment, while its mean value was $1.09 \pm 0.92 \mathrm{mU} / \mathrm{ml}$ in control group, $P$ value $<0.01$ (Table 4 ), also in the same treated group

Table 1. Sex distribution of the studied groups

\begin{tabular}{lcc}
\hline Sex & Chronic HCV children $(n=50)$ & Control $(\mathrm{n}=50)$ \\
\hline Male, $\mathrm{n}(\%)$ & $32(64.0)$ & $30(60.0)$ \\
Female, $\mathrm{n}(\%)$ & $18(36.0)$ & $20(40.0)$ \\
\hline
\end{tabular}

$\mathrm{HCV}$, hepatitis $\mathrm{C}$ virus.

Table 2. Age and body mass index among studied groups

\begin{tabular}{lcc}
\hline Parameter & $\begin{array}{c}\text { Chronic HCV children } \\
(\mathrm{n}=50)\end{array}$ & $\begin{array}{c}\text { Control group } \\
(\mathrm{n}=50)\end{array}$ \\
\hline Age $(\mathrm{yr})$ & $11.3527 \pm 3.1328$ & $11.474 \pm 4.115$ \\
Body mass index $\left(\mathrm{kg} / \mathrm{m}^{2}\right)$ & $19.1 \pm 3.3$ & $19.6 \pm 2.9$ \\
\hline
\end{tabular}

Values are presented as mean \pm standard deviation. $\mathrm{HCV}$, hepatitis $\mathrm{C}$ virus. 
Table 3. Serum TSH, FT3, and FT4 in the interferon treated group before and after treatment

\begin{tabular}{lccl}
\hline Parameter & $\begin{array}{c}\text { Before treatment } \\
(\mathrm{n}=50)\end{array}$ & $\begin{array}{c}\text { After treatment } \\
(\mathrm{n}=50)\end{array}$ & $P$ value \\
\hline TSH $(\mathrm{mU} / \mathrm{mL})$ & $1.16 \pm 0.77$ & $3.23 \pm 88.00$ & $<0.01$ \\
FT3 $(\mathrm{pmol} / \mathrm{L})$ & $4.42 \pm 0.50$ & $4.24 \pm 0.33$ & $>0.5$ \\
FT4 $(\mathrm{pmol} / \mathrm{L})$ & $17.44 \pm 0.24$ & $17.05 \pm 29.00$ & $>0.5$ \\
\hline
\end{tabular}

Values are presented as mean \pm standard deviation.

TSH, thyroid stimulating hormone; FT3, free triiodothyronine; FT4, free thyroxin.

Boldface indicates a statistically significant difference with $P<0.05$.

Table 4. Serum TSH, FT3, and FT4 in the interferon treated group (at the end of treatment) compared with normal control group

\begin{tabular}{lccl}
\hline Parameter & $\begin{array}{c}\text { Before treatment } \\
(\mathrm{n}=50)\end{array}$ & $\begin{array}{c}\text { After treatment } \\
(\mathrm{n}=50)\end{array}$ & $P$ value \\
\hline TSH $(\mathrm{mU} / \mathrm{mL})$ & $3.23 \pm 88.00$ & $1.09 \pm 0.92$ & $<0.01$ \\
FT3 $(\mathrm{pmol} / \mathrm{L})$ & $4.24 \pm 0.33$ & $4.33 \pm 0.48$ & $>0.5$ \\
FT4 $(\mathrm{pmol} / \mathrm{L})$ & $17.05 \pm 29$ & $17.28 \pm 0.24$ & $>0.5$ \\
\hline
\end{tabular}

Values are presented as mean \pm standard deviation.

TSH, thyroid stimulating hormone; FT3, free triiodothyronine; FT4, free thyroxin.

Boldface indicates a statistically significant difference with $P<0.05$.

Table 5. Serum TSH, FT3, and FT4 of Interferon treatment responders and nonresponders at the end of treatment

\begin{tabular}{lccc}
\hline Parameter & $\begin{array}{c}\text { Responders } \\
(\mathrm{n}=29)\end{array}$ & $\begin{array}{c}\text { Nonresponders } \\
(\mathrm{n}=21)\end{array}$ & $P$ value \\
\hline TSH $(\mathrm{mU} / \mathrm{mL})$ & $3.34 \pm 0.74$ & $3.29 \pm 0.82$ & $>0.5$ \\
FT3 $(\mathrm{pmol} / \mathrm{L})$ & $4.6 \pm 0.33$ & $4.51 \pm 0.52$ & $>0.5$ \\
FT4 $(\mathrm{pmol} / \mathrm{L})$ & $17.53 \pm 0.61$ & $17.67 \pm 0.50$ & $>0.5$
\end{tabular}

Values are presented as mean \pm standard deviation.

TSH, thyroid stimulating hormone; FT3, free triiodothyronine; FT4, free thyroxin.

mean TSH was $1.16 \pm 0.77 \mathrm{mU} / \mathrm{mL}$ before therapy and $3.23 \pm 88$ $\mathrm{mU} / \mathrm{mL}$ at the end of treatment, $P$-value $<0.01$ (Table 3 ).

In responders, at the end of therapy (24 weeks), FT3 was $4.6 \pm 0.33 \mathrm{pmol} / \mathrm{L}, \mathrm{FT} 4$ was $17.53 \pm 0.61 \mathrm{pmol} / \mathrm{L}$, and TSH was $3.34 \pm 0.74 \mathrm{mU} / \mathrm{mL}$ (Table 5). Nonresponders' group at the end of therapy (24 weeks), FT3 was $4.51 \pm 0.52 \mathrm{pmol} / \mathrm{L}$, FT4 was $17.67 \pm 0.50 \mathrm{pmol} / \mathrm{L}$, and TSH was $3.29 \pm 0.82 \mathrm{mU} / \mathrm{ml}$ (Table 5).

Antithyroglobulin antibodies and antithyroid peroxidase antibodies were done only in 1 patient (TSH: $14 \mathrm{mU} / \mathrm{mL}$ ). It was negative.

Hypothyroidism can be classified into grades I, II, and III. Grade1 (subclinical hypothyroidism), can be subclassified into grade IA (TSH $>4.0$ to $<10 \mathrm{mU} / \mathrm{L}$ ) and grade IB $(\geq 10 \mathrm{mU} / \mathrm{L})$. Grade II is characterized by elevated TSH associated with decreased FT4 level. Grade III is characterized by elevated TSH and decreased level of both FT4 and FT3.8)

Our study showed that $28 \%$ of children received combined PEG IFN- $\alpha$ plus ribavirin showed subclinical hypothyroidism. Those patients were referred to endocrinologists for followup. No one of our patients showed manifestations of hyperthyroidism.

\section{Discussion}

Thyroiditis is one of the most common side-effects of IFN- $\alpha$ therapy. In our study subclinical hypothyroidism was observed in $26 \%$ of children received combined PEG IFN- $\alpha$ plus ribavirin. TSH ranged between $4-10 \mathrm{mU} / \mathrm{mL}$ in $26 \%$, while it was $>10$ $\mathrm{mU} / \mathrm{mL}$ in $2 \%$. This runs in harmony with other study, ${ }^{9)}$ who reported subclinical hypothyroidism in $20 \%-40 \%$ of patients and clinical hypothyroidism in 5\%-10\%.

In our current study, the overall incidence of thyroid dysfunction was $28 \%$. All affected cases showed hypothyroidism, most of them are subclinical. No cases were reported with hyperthyroidism or biphasic thyroiditis. That was different with Moncoucy et al.. ${ }^{10)}$ who reported $2.8 \%$ of total patients (15\% of positive cases) showed biphasic thyroiditis. This difference may be due to different age groups.

The pathogenesis of IFN-induced thyroid diseases is due to dysregulation of the immune system by IFN, as well as its direct effects on thyroid cells. Increased expression of IFN- $\gamma$ and chemokine ligand 10 has also been reported in patients with autoimmune thyroiditis and hypothyroidism. Our study did not show any positive autoantibodies, in difference with other studies $^{11)}$ that reported the incidence of interferon-induced thyroid autoimmunity from $2.5 \%$ to $42 \%$. That may be due to the fact that he studied different age group. Most of our patients were pubertal males. Carella et al. ${ }^{12}$ documented a genetic predisposition to thyroid autoimmune disease is probably necessary for the development of thyroid disease in patients treated with IFN.

Some studies demonstrated that HCV patients with positive autoantibodies at the initiation of therapy have an $80 \%$ probability of developing thyroid disease during or after therapy, ${ }^{13)}$ while in our study only one patient investigated for autoantibodies.

Ribavirin is a synthetic guanoside nucleoside analog. It has immunomodulatory effects by inducing Th1 cytokines in the immune response against HCV infection (Tam RC). The mean incidence of thyroid dysfunction in patients treated with IFNalpha plus ribavirin therapy is higher than in those treated with IFN alone. Ribavirin could induce hypothyroidism by Th1dependent activation of $\mathrm{CD}^{+} \mathrm{T}$ lymphocytes which induce cellular destruction predominantly by the perforin pathway. ${ }^{14)}$

In the current study, patients received PEG IFN- $\alpha$ plus ribavirin had statistically significant difference regarding the level TSH at the end of treatment in comparison with normal control group (Table1). There was statistically significant difference in same patients group before starting treatment and at the end of treatment (Table 2). Fourteen patients showed elevated TSH level, with statistically significant difference $(P<0.01)$. TSH level ranged from $4-10 \mathrm{mU} / \mathrm{mL}$ in 13 patients while it was more than $10 \mathrm{mU} / \mathrm{mL}$ in 1 patient only. Both FT4 and FT3 did not show any statistical difference between the 2 groups. So, 30\% of children received combined PEG IFN- $\alpha$ plus ribavirin showed subclinical hypothyroidism. No one of our patients showed clinical hypo- 
thyroidism, thyroid antibodies, or manifestations of hyperthyroidism. These findings differ from other study report by Monzani et al. ${ }^{15)} \mathrm{He}$ studied 31 patients with multiple sclerosis whom received 1-year interferon therapy. His results showed that 5 patients were affected by Hashimoto's thyroiditis at baseline, 8 developed thyroid dysfunction and/or autoimmunity of various degrees during IFN-b1b treatment, while 18 did not develop any thyroid abnormality. This difference may be explained by different age group, duration of treatment in addition to different interferon used.

$\mathrm{HCV}$ is a leading cause of chronic hepatic disease, cirrhosis and HCC. Reports stated that almost 170 million persons all over the world are infected with $\mathrm{HCV}$ with a global prevalence of about $3 \%$. Every year there are estimates of 3 to 4 million new cases of infection due to different causes of transmission. However, it is noticed that the incidence of HCV has either declined or stabilized in recent years. ${ }^{16)}$

Chronic HCV infection has an extrahepatic presentation including hematologic diseases, renal disease, dermatologic conditions (such as lichen planus), porphyria, cryoglobulinemia, lymphoma, autoimmune disorders (such as thyroiditis), and the presence of autoantibodies. ${ }^{17)}$

Antonelli et al., ${ }^{18)}$ reported that thyroid disorders are common in patients with chronic HCV, particularly women. Antithyroid antibodies were present in 5\%-17\% of patients. Thyroid diseases, primarily hypothyroidism, occur in $2 \%$ to $13 \%$ of patients and up to $25 \%$ have thyroid antibodies.

This study did not find any corelation between chronic HCV infection in children and thyroid disease as no one of our patients had any thyroid disturbance before initiating therapy. Other studies failed to show that HCV is an independent factor for thyroid diseases, although the rate of antithyroglobulin positivity in $\mathrm{HCV}$ patients was higher than healthy controls. ${ }^{19)}$

Further studies on larger number of patients and longer follow-up duration are recommended for further confirmation of our findings. It may be advisable to follow thyroid functions routinely in children treated with IFN-alpha and ribavirin every 3-6 months, to interfere early if hypothyroidism was detected.

Finally, this study concluded that there is an association between subclinical thyroid dysfunction and treatment with IFN-alpha and ribavirin in children.

See the commentary "Strategies for treating and managing chronic hepatitis $\mathrm{C}$ in children in the direct-acting antiviral era" in Volume 63 on page 46.

\section{Conflicts of interest}

No potential conflict of interest relevant to this article was reported.

\section{References}

1. Iliescu EL, Mercan-Stanciu A, Toma L, Ioanitescu ES, Dumitru R, Rusie D. Hepatocellular carcinoma in the setting of interferon free treatment for chronic HCV hepatitis - experience of a single center. Hepatoma Res 2018;4:3.

2. Abd-Elgawad MM, Baddour NM, Salem MA. Chronic hepatitis C in children: clinical spectrum and histopathological study. Alexandria Journal of Medicine 2013;49:363-8.

3. El-Guindi MA. Hepatitis C viral infection in children: updated review. Pediatr Gastroenterol Hepatol Nutr 2016;19:83-95.

4. Mack CL, Gonzalez-Peralta RP, Gupta N, Leung D, Narkewicz MR, Roberts EA, et al. NASPGHAN practice guidelines: diagnosis and management of hepatitis $\mathrm{C}$ infection in infants, children, and adolescents. J Pediatr Gastroenterol Nutr 2012;54:838-55.

5. Stallings-Smith S, Krull KR, Brinkman TM, Hudson MM, Ojha RP. Longterm follow-up for incident cirrhosis among pediatric cancer survivors with hepatitis C virus infection. J Clin Virol 2015;71:18-21.

6. Wirth S. Current treatment options and response rates in children with chronic hepatitis C. World J Gastroenterol 2012;18:99-104.

7. Wang CC, Krantz E, Klarquist J, Krows M, McBride L, Scott EP, et al. Acute hepatitis $\mathrm{C}$ in a contemporary US cohort: modes of acquisition and factors influencing viral clearance. J Infect Dis 2007;196:1474-82.

8. Wiersinga WM. Guidance in subclinical hyperthyroidism and subclinical hypothyroidism: are we making progress? Eur Thyroid J 2015;4:143-8.

9. Tomer Y, Menconi F. Interferon induced thyroiditis. Best Pract Res Clin Endocrinol Metab 2009;23:703-12.

10. Moncoucy X, Leymarie F, Delemer B, Lévy S, Bernard-Chabert B, Bouché $\mathrm{O}$, et al. Risk factors and long-term course of thyroid dysfunction during antiviral treatments in 221 patients with chronic hepatitis C. Gastroenterol Clin Biol 2005;29:339-45.

11. Andrade LJ, Atta AM, D'Almeida Junior A, Paraná R. Thyroid dysfunction in hepatitis $\mathrm{C}$ individuals treated with interferon-alpha and ribavirin-a review. Braz J Infect Dis 2008;12:144-8.

12. Carella C, Mazziotti G, Morisco F, Manganella G, Rotondi M, Tuccillo C, et al. Long-term outcome of interferon-alpha-induced thyroid autoimmunity and prognostic influence of thyroid autoantibody pattern at the end of treatment. J Clin Endocrinol Metab 2001;86:1925-9.

13. Vasiliadis T, Anagnostis P, Nalmpantidis G, Soufleris K, Patsiaoura K, Grammatikos N, et al. Thyroid dysfunction and long-term outcome during and after interferon-alpha therapy in patients with chronic hepatitis C. Ann Acad Med Singapore 2011;40:394-400.

14. Koh LK, Greenspan FS, Yeo PP. Interferon-alpha induced thyroid dysfunction: three clinical presentations and a review of the literature. Thyroid 1997;7:891-6.

15. Monzani F, Caraccio N, Meucci G, Lombardo F, Moscato G, Casolaro A, et al. Effect of 1-year treatment with interferon-beta1b on thyroid function and autoimmunity in patients with multiple sclerosis. Eur J Endocrinol 1999;141:325-31.

16. World Health Organization. Global hepatitis [Internet]. Geneva (Switzerland): World Health Organization, 2007.

17. El-Serag HB, Hampel H, Yeh C, Rabeneck L. Extrahepatic manifestations of hepatitis C among United States male veterans. Hepatology 2002;36: $1439-45$

18. Antonelli A, Ferri C, Pampana A, Fallahi P, Nesti C, Pasquini M, et al. Thyroid disorders in chronic hepatitis C. Am J Med 2004;117:10-3.

19. Floreani A, Betterle C, Carderi I, Presotto F, Pedini B, Moscon A, et al. Is hepatitis $\mathrm{C}$ virus a risk factor for thyroid autoimmunity? J Viral Hepat 2006;13:272-7. 